\title{
Humoral Immune Responses and Hepatitis B Infection
}

\author{
Ashish Kumar Vyas ${ }^{\text {a }}$ Mojahidul Islam ${ }^{\mathrm{b}}$ Garima Garg ${ }^{\mathrm{a}}$ Anirudh K. Singh ${ }^{\mathrm{a}}$ \\ Nirupma Trehanpati ${ }^{\text {b }}$ \\ aDepartment of Microbiology, All India Institute of Medical Sciences, Bhopal, India; ${ }^{b}$ Departments of Molecular and \\ Cellular Medicine, Institute of Liver \& Biliary Sciences, New Delhi, India
}

\section{Keywords}

Hepatitis B - Chronic hepatitis B virus - Immune response -

T follicular helper cells · Antibody · Interleukin-21

\begin{abstract}
Background: Chronicity or seroclearance of hepatitis $B$ virus (HBV) antigens is determined by the host immune responses. Current approaches to treat HBV patients are based on inhibition of replication using different antivirals (nucleoside or nucleotide analogs) as monotherapy, or along with immune modulators as combination therapy is being used worldwide for reducing the viral load. Understanding the role of immune cellular therapies with currently available treatments for persistent viral-mediated responses in HBV patients is unexplored. However, the generation of antibodies against a surface ( $\mathrm{HBs}$ ) and envelop ( $\mathrm{HBe}$ ) antigen of hepatitis $B$ remains an issue for future studies and needs to be explored. Summary: Humoral immunity, specifically $T$ follicular helper (TFh) cells, may serve as a target for therapy for HBsAg seroconversion. In this review, we have been engrossed in the importance and role of the humoral immune responses in CHBV infection and vertical transmission. Key Message: TFh cells have been suggested as the potential target of immunotherapy which lead to seroconversion of $\mathrm{HBe}$
\end{abstract}

and $\mathrm{HBs}$ antigens of HBV. HBsAg seroconversion and eradication of covalently closed circular DNA are the main challenges for existing and forthcoming therapies in HBV infection.

(c) 2021 S. Karger AG, Basel

\section{Introduction}

Chronic hepatitis $\mathrm{B}$ virus (CHBV) infection is a significant health problem with a projected 240 million carriers worldwide. Around half a million people die each year because of the advancement of the infection to liver fibrosis, cirrhosis, and hepatocellular carcinoma (HCC) [1-3]. This is a bigger problem for Asia as the continent contributes to the majority of the global HBV infections. India has approximately 3-4\% HBV carriers among 1.35 billion [4] and considered as the second major pool of HBV patients [5].

Maternofetal transmission is one of the main causes of the persistence of the HBV and the development of chronicity [6]. The prevalence of CHBV among pregnant women is witnessed to be $0.82 \%$ and found to be associated with the risk of mother-to-child transmission [7]. Chronicity of HBV infection is inversely proportional to 
the age, and newborns have higher chance of getting a chronic infection (90-95\%) as compared to adults (5$10 \%)$ [8]. While in many countries vaccination has decreased the high burden of HBV and related complications, the currently available therapies for $\mathrm{CHBV}$ patients are inadequate. The currently recommended nucleoside analog therapy has little effect on HBsAg levels, HBsAg loss, and depletion of cccDNA [9]. Another major problem with long-term nucleoside analog therapy is emergence of resistance [10].

In the past 2 decades, HBsAg seroconversion is rare, and the pool of cccDNA in the nucleus is a major reason for the persistence of HBV. A number of studies addressed the issues pertaining to epidemiology, genotypes, viral mutations, and immunology of HBV [11]. The CHBV patients showed an impaired immune profile [12, 13], especially dysfunctional $\mathrm{HBV}$-specific CD8+ T-cell responses [14]. T follicular helper (TFh) cell is a subset of the helper $\mathrm{T}$-cell population and has shown a crucial role in the seroconversion of $\mathrm{HBe}$ and HBsAg in CHBV-infected patients $[15,16]$.

Recently, our group showed that B and TFh cells have also emerged as an essential player in preventing viral expansion within the host and involved in $\mathrm{HBeAg}$ [17] or HBsAg seroconversion along with CD8 T-cell responses [13]. The generation of antibodies against HBsAg or HBeAg seroconversion remains to be explored. Limited but compelling experimental evidence suggests that modulation of TFh cells can be an exciting prospect for achieving seroconversion of $\mathrm{HBsAg}$ in $\mathrm{CHBV}$ infections. In this review, we make a case for the role of TFh and B cells in seroconversion and their importance in $\mathrm{CHBV}$ infection.

For this review, PubMed was searched to summarize the available studies in the area of hepatitis B humoral immunity. Only published studies in English were reviewed and summarized with data. Importance has been given to well-established studies with high citation.

\section{Hepatitis B Infection}

HBV is a partially double-stranded DNA virus which is noncytopathic, but hepatotoxicity of the liver occurs due to vigorous proinflammatory immune cell activation in response to viral infection. Being a hepatotropic virus, HBV enters the blood and then replicates in the liver. Although the accurate mechanism of HBV entry into hepatocytes remains unclear, recent studies documented that HBV pre-S protein facilitates entry into the hepatocytes through the asialoglycoprotein receptor and sodium tau-

Humoral Immunity in Hepatitis B

Infection rocholate co-transporting polypeptide [18-20]. The fate of HBV infection is a result of a key equilibrium between viral replication and host immunity. Most individuals who get HBV infection in adulthood develop icteric acute hepatitis due to vigorous immune response against viruses resulting in self-limiting illness. Less than $1 \%$ of them develop acute liver failure requiring intensive monitoring and early liver transplantation [21,22].

Virological factor and host immune responses govern one of the 3 possible outcomes of the HBV infection: (1) immune tolerance, (2) immune activation, and (3) inactive carrier stage. However, there are abundant similarities and interindividual inconsistencies in these stages. According to EASL 2017 guidelines, "CHBV infection can be classified into 5 phases (I) HBeAg-positive chronic infection, (II) HBeAg-positive chronic hepatitis, (III) $\mathrm{HBeAg}$-negative chronic infection, (IV) HBeAg-negative chronic hepatitis, and (V) HBsAg-negative phase" [23].

On the basis of the presence and disappearance of $\mathrm{HBV}$ antigens (HBsAg, $\mathrm{HBeAg}$, and $\mathrm{HBcAg}$ ) and antibodies (anti-HBs, anti-HBe, and anti-HBc), different phases of CHBV are described (Fig. 1). The immune tolerant phase is characterized by HBeAg positivity, high HBV DNA levels, normal or low levels of alanine aminotransferases (ALT), and minimal liver necroinflammation hardly leading to any progression to fibrosis [24, 25]. However, due to sequential accumulation of $\mathrm{HBV}$ virions or mutation in the core promoter, few patients develop "HBeAg-negative CHB infection" which is also characterized by inconsistent levels of ALT and HBV DNA $>2,000 \mathrm{IU} / \mathrm{mL}$ but with active hepatitis [26-29].

The immune tolerant phase is followed by the "immune active" phase, characterized by HBeAg positivity, high serum HBV DNA levels, persistent or intermittent increase in ALT levels, moderate or severe liver necroinflammation, and more progression to fibrosis. The extent of liver damage is directly related to the duration of this phase. The immune active phase ends with the seroconversion of $\mathrm{HBeAg}$ and the formation of anti-HBeAb.

The immune active phase is followed by "immune inactive HBV carrier state" which can be identified by very low or undetectable serum HBV DNA levels (below 2,000 $\mathrm{IU} / \mathrm{mL}$ ) and normal ALT. The disease remains stable in this phase due to a very low but ongoing risk of liver-related complications. The spontaneous HBeAg clearance rate varies from 3 to $12 \%$ annually, but a rate of $\mathrm{HBsAg}$ seroconversion is very rare, only $\sim 1 \%[30,31]$. Even after the disappearance of $\mathrm{HBsAg}$, cccDNA still persists in the liver but with a very little risk of further progression of liver disease [32]. 


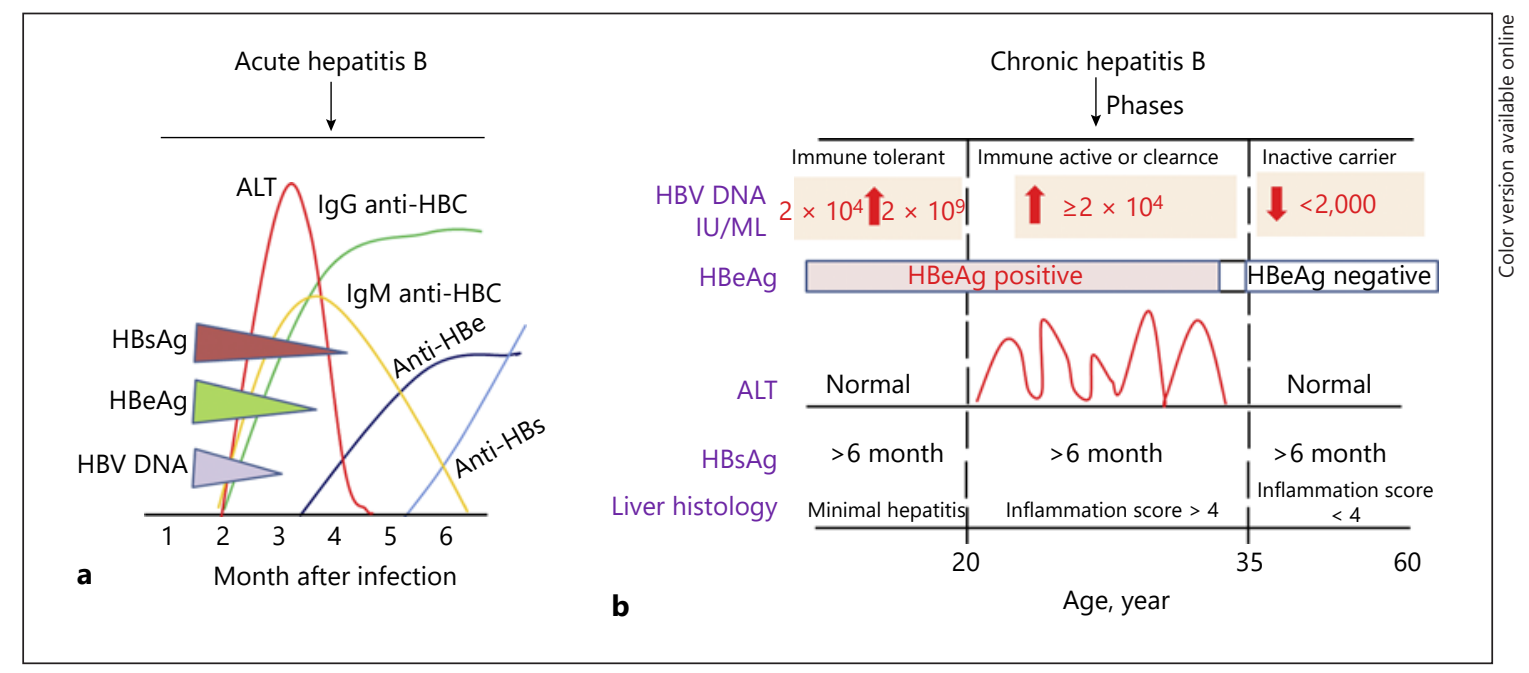

Fig. 1. Infection of HBV is majorly categorized into 2 types: acute and chronic. a Acute HBV infection: HBsAg is the first to be detected in the circulation even 2-6 weeks earlier to the appearance of the symptoms of hepatitis. Presence of $\mathrm{HBs} A g$ together with anti-HBc IgM is considered the hallmark of acute HBV infection. HBc IgM can be seen for approximately 6 months after the acute infection. After that, IgM disappears, and anti-HBc IgG is present lifelong. $\mathbf{b}$ Phases of CHBV infection: on the basis of HBV DNA, HBeAg, and ALT levels. HBV, hepatitis $B$ virus; $\mathrm{CHBV}$, chronic hepatitis B virus; ALT, alanine aminotransferase.

\section{HBV Adaptive Immune Responses and Therapy}

In adaptive immunity, CD8+ $\mathrm{T}$ cells are considered as one of the most important players in HBV infection, which act through cytolytic or noncytolytic mechanisms via the secretion of IFN- $\gamma$ and TNF- $\alpha$ [33]. However, defective virus-specific responses by CD8 cells have been observed in CHBV patients [34]. Even in the presence of profound $\mathrm{DC}$ activation and antigen presentation, $\mathrm{HBV}$ specific CD8+ T-cell exhaustion under continuous exposure to HBV antigens is a major challenge to clear the virus. Regulatory T cells, which are known for downregulation of inflammatory immune responses and maintaining the immune homeostasis, have been shown to fail during chronic HBV infection $[35,36]$. Regulatory T cells maintain immunosuppressive functions by secreting the inhibitory cytokines such as TGF- $\beta$, IL-10, and IL-35 and suppress the activation of antigen-specific or nonspecific proliferation in most of the function of the immune cells $[37,38]$. The current strategy for the restoration of the function of $\mathrm{T}$ cells, blocking or neutralizing the inhibitory receptors (CTLA-4, PD-1, and TIM-3) and cytokines (IL-10 and IL-35) may be effective therapeutic targets in HBV.

Currently available treatments of CHB include standard IFN- $\alpha$, Peg-IFN- $\alpha 2 a$, Peg-IFN- $\alpha 2 b$, and NA (nucleoside analogs [lamivudine, telbivudine, emtricitabine, and entecavir] and nucleotide analogs [adefovir and tenofovir]). A comparison of these antiviral therapies fails to show the superiority of one therapy over another with the aim of risk reduction in liver-related complications $[20,39,40]$. The current, underexploration therapies and immune modulators have been discussed in Table 1.

\section{Mechanisms of HBeAg and HBsAg Seroconversion}

$\mathrm{B}$ cells do not have critical roles in the elimination of viral particles directly [41]. However, B- and TFh-cell responses have been shown to play an important role in preventing viral expansion within the host and also the main players in $\mathrm{HBe}$ or HBsAg seroconversion.

TFh cells reside in the secondary lymphoid organ and help in the B-cell differentiation through the secretion of IL-21 $[42,43]$. TFh cells express distinctive markers, including the transcriptional repressor Bcl6, the chemokine, and the costimulatory molecules such as CXCR5, ICOS, and CD40L (Fig. 2). Translocation of TFh cells toward the CXCL13-rich germinal center is mediated by the CXCR5 expression $[44,45]$. TFh cells have been emerged as a crucial player in B-cell differentiation to form antibody-producing plasma cells that offer lifelong protection [46-48]. It is observed that the absence of TFh cells 
Table 1. Current underexploration therapies and immune modulators

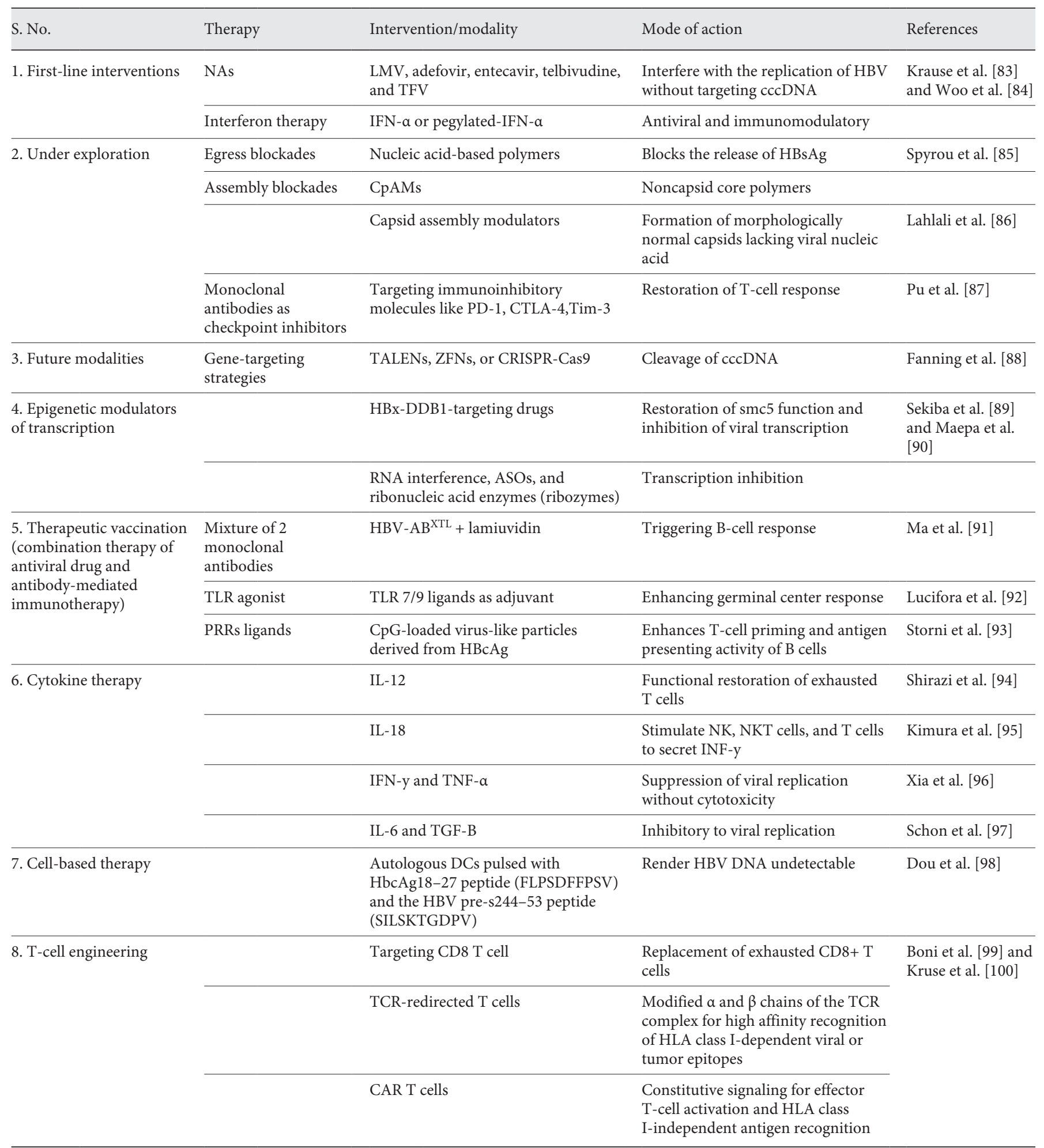

NAs, nucleos(t)ide analogs; LMV, lamivudine; TFV, tenofovir; HBV, hepatitis B virus; CpAMs, core protein allosteric modulators; TALENs, transcription activator-like effector nucleases; ZFNs, zinc-finger nucleases; ASOs, antisense oligonucleotides; CAR, chimeric antigen receptor. 


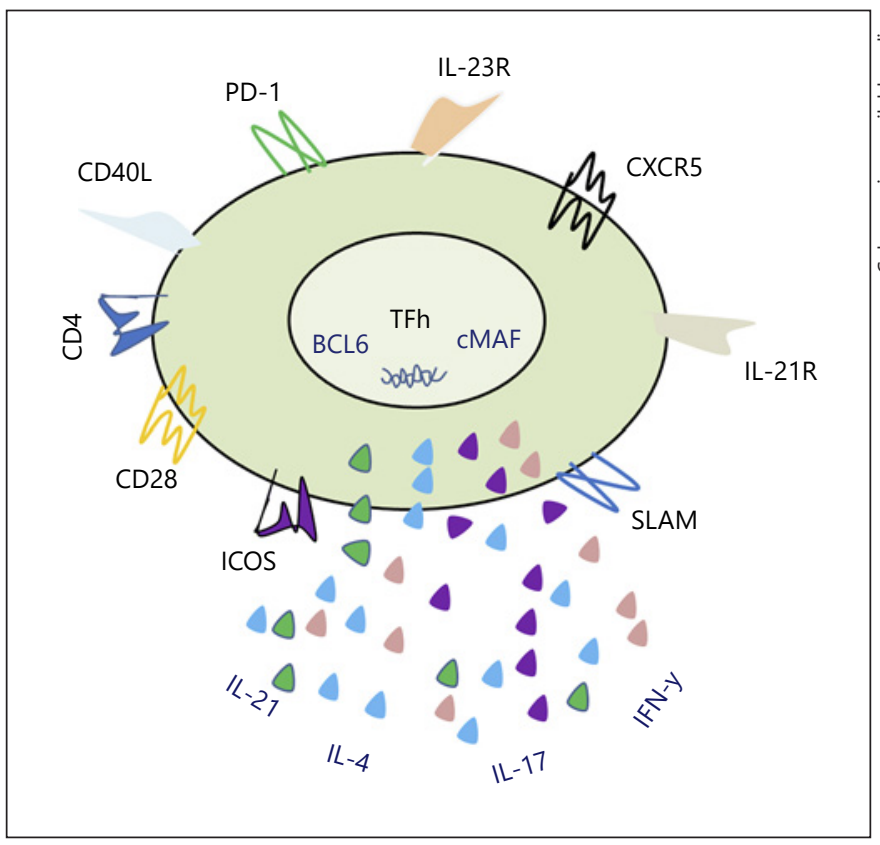

Fig. 2. Phenotypic marker and characterization of TFh cells: TFh cells can be distinguished on the basis of transcription factors (BCL6 and cMAF), costimulatory marker (ICOS), and by secretion of the key cytokine IL-21. TFh, T follicular helper.

at the onset of infection reduces the overall humoral response and prevents viral clearance [43, 49].

High-affinity class-switched antibodies are essential in clearing and establishing long-lasting humoral immunity against $\mathrm{HBV}$ infection and effective vaccination. It is observed that in response to $\mathrm{HBV}$ vaccination, antibody secretion was influenced by genetic polymorphism of CXCR5 and CXCL13 [50].

\section{Importance of IL-21 Cytokine}

TFh cells have a pleiotropic function and secrete many cytokines such as IL-4, IL-2, IL-6, IFN-y, IL-17, and IL21. Production of IL-21 by TFh cells was first described in context of tonsils and was shown to have a specific role in B-cell differentiation [51-54]. Further studies reiterated that IL-21 endows TFh cells to exert B-cell helper functions (Fig. 3) [42, 43, 55]. Therefore, IL-21 has emerged as an essential cytokine for the maturation of $\mathrm{B}$ cells and the clearance of chronic viral infections $[56,57]$. In $\mathrm{HBV}$ pathogenesis, mainly inhibitory cytokines are involved, but now it was observed that IL-21 cytokine has a key role in the therapeutic augmentation of immune responses against HBV [58]. Therefore, IL-21 has emerged as an important cytokine in the maturation of B cells and the clearance of chronic viral infections [56, 57]. Recent studies by McGuire et al. [59] and Weinstein et al. [60] showed that IL-21 is secreted by TFh before IL-4, suggesting that B-cell somatic hypermutation is through IL-21, and plasma cell differentiation is through IL-4 $[59,60]$.

\section{T- and B-Cell Interaction within Germinal Center in HBV}

$\mathrm{T}$ - and B-cell interaction initiates the extra follicular foci or germinal center formation in the secondary lymphoid organ. B-cell clones with high affinity receive maximum ICOSL, CD40, and IL-21 signals, which lead to differentiation and existence into long-lived plasma cells [61-64]. Therefore, the effectiveness of TFh- and B-cell communication in the germinal center is critical for the expansion of memory B cells and formation of plasma cells (Fig. 4). Recent information has also emphasized the role of DCs localized in the interfollicular zone in priming the early-stage TFh cells [65].

\section{The Importance of $\mathrm{HBeAg}$ and $\mathrm{HBsAg}$ Seroconversion in Hepatitis B Infections}

Seroconversion of $\mathrm{HBeAg}$ and $\mathrm{HBsAg}$ is critical for controlling the pathogenesis of CHBV infection, whereas $\mathrm{HBeAg}$ seroconversion is an indicator of inhibition of viral replication, and $\mathrm{HBsAg}$ seroconversion is considered the functional cure of the disease. $\mathrm{HBeAg}$ is considered the marker of replication and seroconversion of $\mathrm{HBeAg}$, and the formation of anti-HBeAb is a critical incident in the history of $\mathrm{CHB}$ infection. Anti-HBeAg formation or seroconversion of $\mathrm{HBeAg}$ is associated with the reduction of HBV DNA. While spontaneous HBeAg seroconversion rate has been described to be between 8 and $15 \%$ [66, 67], HBsAg seroconversion in rare, and only $1-2 \%$ patients achieve this $[31,66,67]$.

Earlier seroconversion of $\mathrm{HBeAg}$ in $\mathrm{CHB}$ patients is found to be associated with an increased chance of sustained remission, as well as slower pathogenesis of the liver disease $[68,69]$. There are many factors such as sex, age, and the degree of liver disease that can affect the rate of HBeAg seroconversion. Patients with older history, female carriers, and subjects with the ALT levels higher than 5 times the upper limit of normal are more likely to clear HBeAg. Peg-IFN- $\alpha$ therapy results in sustained $\mathrm{HBeAg}$ seroconversion rates of up to 32 and $48 \%$, respec- 


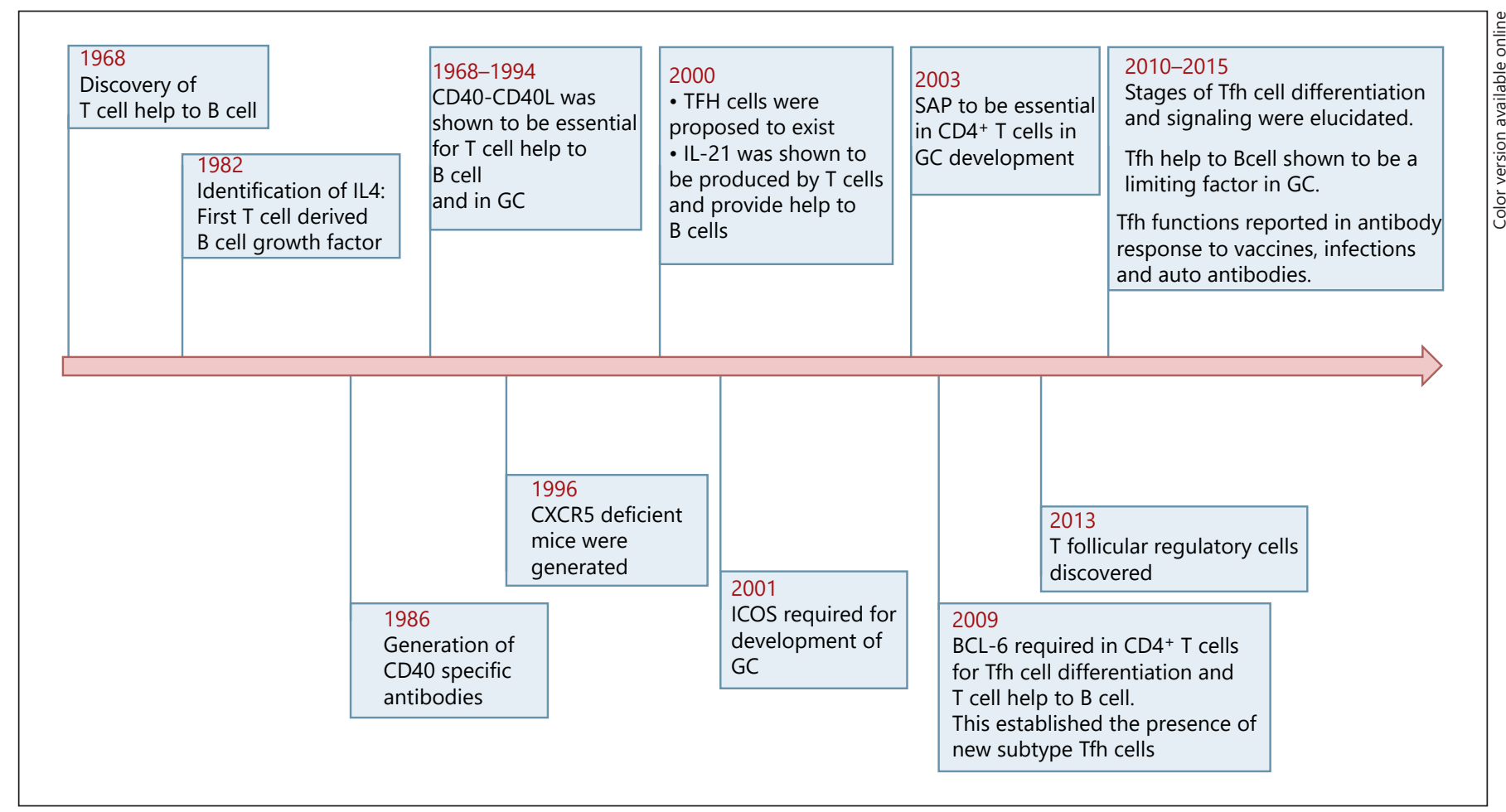

Fig. 3. A history of T cells' help to B cells: the principal signs came from Claman and partners in 1966 [54], supported by a trio of consecutive studies by Miller and Mitchell in 1968.

Fig. 4. T- and B-cell interaction within the germinal center in $\mathrm{HBV}$ : circulating HBV proteins being sensed by circulating DCs. These cells carry HBV antigens and present through MHC to naïve CD4+ T cells and help in T-cell differentiation towards TFh cells. TFh cells drift from the T-cell zone to the B-cell zone in the germinal center, where follicular DCs, TFh, and B cells interact and help in affinity maturation of $B$ cells. The B cells which failed to interact with TFh cells are recycled back into the dark zone where proliferation and somatic hypermutations in B cells take place. Once the $B$ cell gains specificity for a particular HBV antigen, they become plasma cells secreting antigen-specific antibodies on exit from the germinal center. $\mathrm{HBV}$, hepatitis $\mathrm{B}$ virus.

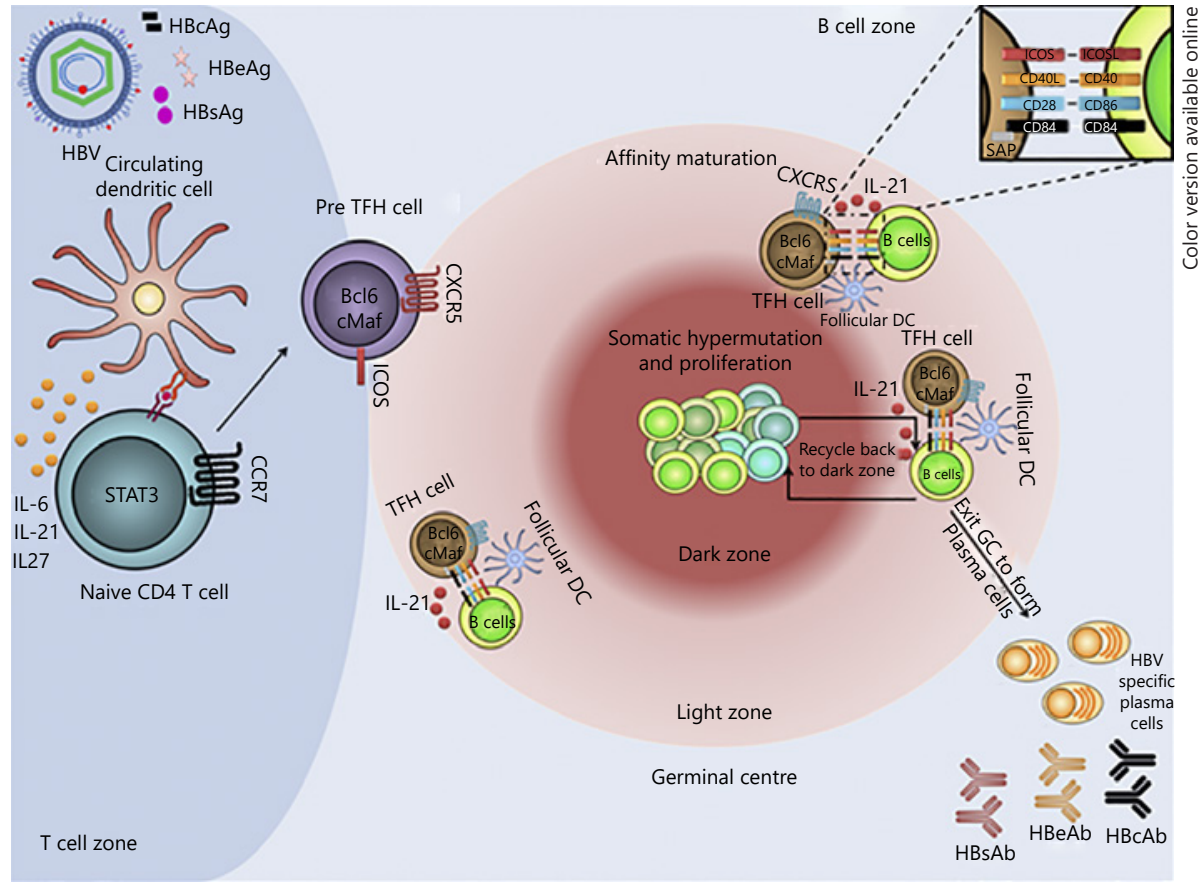

Humoral Immunity in Hepatitis B Infection 
tively, when assessed at weeks 24 and 48 after treatment. In contrast, $\mathrm{HBeAg}$ seroconversion rates have been considerably lower (12-15\%) with nucleotide analogues [70, 71].

The clearance of HBsAg is found to be associated with minimal risk of disease progression such as cirrhosis, decompensation, and HCC. But, if cirrhosis has developed before the disappearance of $\mathrm{HBsAg}$, patients will be at risk of HCC. Long-term NA therapy decreased the viral load, but it is only effective in a minority of $\mathrm{CHB}$ patients for seroconversion of HBsAg [72, 73].

\section{The Role of TFh Cells in Inducing $\mathrm{HBeAg}$ and $\mathrm{HBsAg}$ Seroconversion}

The presence of $\mathrm{HBeAg}$ and $\mathrm{HBsAg}$ is considered as a marker of HBV replication and infection. Therefore, the secretion of antibodies against the HBV antigen, specifically $\mathrm{HBe}$ and $\mathrm{HBsAg}$, is considered a favorable outcome of CHBV infection. Collected evidence has believed the liver worked like other secondary lymphoid organs, and it supports the priming of naïve $\mathrm{T}$ cells for differentiation of effector T cells [74-76].

Recently, studies using animal models of HBV have demonstrated that the immune response depends upon the age, and young age is found to be associated with effective immune stimulation and antiviral immunity [58, 77]. Furthermore, the hepatic lymphoid structures had the ability to take care of the differentiation as well as the maturation of B-cell-mediated responses and the priming of T cells to become TFh cells [77]. The animal model study has also found that the presence of IL-21-secreting TFh cells and IgG-expressing B cells in the liver is essential for effective priming of the humoral immune response leading to antibodies against HBsAg [58]. Adult mice, lacking IL-21R on the donor splenocytes, were found incapable to producing antibodies against HBsAg, and subsequent persistence of HBV occurs [58].

Another longitudinal study on a cohort of telbivudinetreated patients revealed that seroconversion of $\mathrm{HBeAg}$ was related to increase in IL-21 concentrations in the circulation at week 12 and considered as an independent predictor for HBV clearance [56, 78]. Other studies also supported indirectly where they showed that the disappearance of $\mathrm{HBeAg}$ is linked with higher CD4+ T-cell responses in HBeAg-positive patients after adefovir dipivoxil treatment [79]. Recent studies from our groups and others showed that immune active $\mathrm{CHB}$ patients had higher occurrences of peripheral blood TFh cells and IL-
21 levels and suggested that it could play a key role in $\mathrm{HBe}$ and HBs seroconversion $[13,46,56,80]$.

\section{Role of Humoral Immunity in Hepatitis B Vertical Transmission}

Mother-to-baby vertical transmission of $\mathrm{HBV}$ is one of the leading causes of CHBV infection in the Association of Southeast Asian Nations (ASEAN) countries. However, there are limited studies available on the role or association of maternal and newborn immunity in vertical transmission of HBV. According to the observation of Shrivastava et al. [81], hepatitis B surface antigen-positive infants showed higher numbers of immature transitional $B$ cells at birth, which normalized a year after immunization. In this study, the authors conclude that the immature $\mathrm{B}$-cell response to neonatal $\mathrm{HBV}$ exposure is associated with maternal-child transmission of HBV. Recently, we for the first time reported the role of maternal immunity, specifically humoral immunity, in mother-to-baby vertical transmission [82]. We found that mothers who did not transfer the virus vertically have higher TFh and plasma B-cell frequencies, as well as IL-21 levels in circulation compared to a mother who did so. Interestingly, we also observed that newborns showed immune imprints of their mothers (positive newborn born from HBV-infected mother compared to negative newborns born from HBV-positive mothers) [82]. While these observations testify for the importance of humoral immune status of the mother baby pair, studies with larger cohorts are needed to substantiate the findings.

\section{Challenges Ahead and Conclusion}

Targeting and elimination the HBV cccDNA which acts as a template for the transcription and persistence of HBV RNAs and seroconversion of HBsAg is considered a complete cure of HBV infection. It is well documented that $\mathrm{CDNA}$ acts as a reservoir of $\mathrm{HBV}$ and persists in the nucleus. The current treatment for CHBV patients is antivirals and traditional immune modulators. However, they have their own limitations such as drug resistance, flu-like symptoms, and other side effects. For the functional cure of HBV clearance, there is a need to introduce rationale-based newer immune modulators and cytokine adjuvants which induce protective host immune responses for seroconversion and target cccDNA and cellular host proteins for viral entry and replication. Research 
from the past 2 decades has provided clues of the role of humoral immune response in HBV infection.

However, major knowledge gaps, specifically in TFh cell biology, remain. On the basis of the current understanding of available data in animal models and in CHBV patients, we conclude that IL-21-producing TFh cells represent a major mediator along with CD8 $\mathrm{T}$ and innate immunity for the induction and maintenance of $\mathrm{HBeAg}$ and HBsAg seroconversion and antigen clearance. There is a need to have a larger cohort of human studies for understanding the role of TFh biology in CHBV infection. It is also important for understanding the mechanism and their role in $\mathrm{HBs}$ and $\mathrm{HBeAg}$ seroconversion. The knowledge related to humoral responses in HBV vertical transmission and the understanding of the failure of $\mathrm{HBV}$ vaccination in HBV-infected babies born from HBV-infected mothers is also limited.

\section{Conflict of Interest Statement}

There are no conflicts of interest among the authors.

\section{Funding Sources}

This study was funded by the Department of Science and Technology, Govt. of India (Grant No. DST/INSPIRE/04/2018/000019).

\section{Author Contributions}

A.K.V. conceptualized and drafted the manuscript, M.I. and G.G. were responsible for figure draft and literature survey, and A.K.S. and N.T. critically revised and edited the manuscript.

\section{References}

1 Lee WM. Hepatitis B virus infection. N Engl J Med. 1997 Dec 11;337(24):1733-45.

2 Lok A. Hepatitis B: liver fibrosis and hepatocellular carcinoma. Gastroenterol Clin Biol. 2009;33(10-11):911-5.

3 Vyas AK, Jindal A, Hissar S, Ramakrishna G, Trehanpati N. Immune balance in hepatitis B infection: present and future therapies. Scand J Immunol. 2017;86(1):4.

4 Puri P. Tackling the hepatitis B disease burden in India. J Clin Exp Hepatol. 2014 Dec; 4(4):312-9.

5 Trehanpati N, Hissar S, Shrivastav S, Sarin SK. Immunological mechanisms of hepatitis $B$ virus persistence in newborns. Indian J Med Res. 2013 Nov;138(5):700-10.

6 Sarin SK, Kumar M, Shrivastava S, Sinha S, Pati NT. Influence of chronic HBV infection on pregnancy: a human model of maternofetal virus host interactions. Gastroenterology. 2011 Oct;141(4):1522-5.

7 Pande C, Sarin SK, Patra S, Bhutia K, Mishra SK, Pahuja S, et al. Prevalence, risk factors and virological profile of chronic hepatitis B virus infection in pregnant women in India. J Med Virol. 2011 Jun; 83(6):962-7.

8 Poynard T. [Do the interferons have an antifibrotic action? The hepatologist's point of view]. Rev Med Interne. 2002 Nov;23(Suppl 4):517s-21s.

9 Werle-Lapostolle B, Bowden S, Locarnini S, Wursthorn K, Petersen J, Lau G, et al. Persistence of cccDNA during the natural history of chronic hepatitis B and decline during adefovir dipivoxil therapy. Gastroenterology. 2004; 126(7):1750-8.

10 Zoulim F. Hepatitis B virus resistance to antiviral drugs: where are we going? Liver Int. 2011;31 Suppl 1:111-6.
11 Teo E-K, Lok AS. Epidemiology, transmission, and prevention of hepatitis B virus infection.

12 Tan A, Koh S, Bertoletti A. Immune response in hepatitis B virus infection. Cold Spring Harb Perspect Med. 2015;5(8):a021428.

13 Vyas AK, Sharma BC, Sarin SK, Trehanpati $\mathrm{N}$. Immune correlates of hepatitis B surface antigen spontaneous seroconversion in hepatitis B e antigen negative chronic hepatitis B patients. Liver Int. 2018 Jan;38(1): 38-49.

14 Kurktschiev PD, Raziorrouh B, Schraut W, Backmund M, Wächtler M, Wendtner CM, et al. Dysfunctional CD8+ T cells in hepatitis B and $\mathrm{C}$ are characterized by a lack of antigenspecific T-bet induction. J Exp Med. 2014; 211(10):2047.

15 Gupta E, Kumar A, Choudhary A, Kumar M, Sarin SK. Serum hepatitis B surface antigen levels correlate with high serum HBV DNA levels in patients with chronic hepatitis B: a cross-sectional study. Indian J Med Microbiol. 2012 Apr-Jun;30(2):150-4.

16 Vyas AK, Sharma BC, Sarin SK, Trehanpati $\mathrm{N}$. Immune correlates of hepatitis B surface antigen spontaneous seroconversion in hepatitis $\mathrm{B}$ e antigen negative chronic hepatitis $\mathrm{B}$ patients. Liver Int. 2018;38(1):38-49.

17 Wang GQ, Ding YP, Dong YH. Telbivudine treatment is associated with high hepatitis B e antigen seroconversion and immune modulatory effects in chronic hepatitis B patients. J Viral Hepat. 2013;20 Suppl 1(s1): 9-17.

18 Yan H, Peng B, He W, Zhong G, Qi Y, Ren B, et al. Molecular determinants of hepatitis $B$ and $D$ virus entry restriction in mouse sodium taurocholate cotransporting polypeptide. J Virol. 2013;87(14):7977-91.
19 Yan H, Peng B, Liu Y, Xu G, He W, Ren B, et al. Viral entry of hepatitis $B$ and $D$ viruses and bile salts transportation share common molecular determinants on sodium taurocholate cotransporting polypeptide. J Virol. 2014; $88(6): 3273$

20 Vyas AK, Jindal A, Hissar S, Ramakrishna G, Trehanpati N. Immune balance in hepatitis B infection: present and future therapies. Scand J Immunol. 2017;86(1):4-14.

21 Rapicetta M, Ferrari C, Levrero M. Viral determinants and host immune responses in the pathogenesis of HBV infection. J Med Virol. 2002;67(3):454-7.

22 Watashi K, Sluder A, Daito T, Matsunaga S, Ryo A, Nagamori S, et al. Cyclosporin A and its analogs inhibit hepatitis $B$ virus entry into cultured hepatocytes through targeting a membrane transporter, sodium taurocholate cotransporting polypeptide (NTCP). Hepatology. 2014;59(5):1726-37.

23 European Association for the Study of the Liver. EASL 2017 Clinical Practice Guidelines on the management of hepatitis B virus infection. J Hepatol. 2017;67(2):370-98.

24 Fattovich G. Natural history and prognosis of hepatitis B. Seminars in liver disease. 2003 Feb;23(1):47-58

25 Hoofnagle JH, Doo E, Liang TJ, Fleischer R, Lok AS. Management of hepatitis B: summary of a clinical research workshop. Hepatology. 2007 Apr;45(4):1056-75.

26 Brunetto MR, Giarin M, Oliveri F, Saracco G, Barbera C, Parrella T, et al. 'e' antigen defective hepatitis B virus and course of chronic infection. J Hepatol. 1991;13(Suppl 4): S82-6.

27 Hadziyannis SJ, Vassilopoulos D. Hepatitis B e antigen-negative chronic hepatitis B. Hepatology. 2001 Oct;34(4 Pt 1):617-24.
Humoral Immunity in Hepatitis B Infection 
28 Brunetto MR, Oliveri F, Coco B, Leandro G, Colombatto P, Gorin JM, et al. Outcome of anti-HBe positive chronic hepatitis B in alpha-interferon treated and untreated patients: a long term cohort study. J Hepatol. 2002 Feb;36(2):263-70.

29 Hadziyannis SJ, Papatheodoridis GV. Hepatitis $\mathrm{B}$ e antigen-negative chronic hepatitis $\mathrm{B}$ : natural history and treatment. Semin Liver Dis. 2006 May;26(2):130-41.

30 Martinot-Peignoux $M$, Boyer N, Colombat M, Akremi R, Pham BN, Ollivier S, et al. Serum hepatitis $B$ virus DNA levels and liver histology in inactive HBsAg carriers. J Hepatol. 2002 Apr;36(4):543-6.

31 Cheng HR, Liu CJ, Tseng TC, Su TH, Yang $\mathrm{HI}$, Chen CJ, et al. Host genetic factors affecting spontaneous $\mathrm{HBsAg}$ seroclearance in chronic hepatitis B patients. PLoS One. 2013; 8(1):e53008.

32 Raimondo G, Allain JP, Brunetto MR, Buendia MA, Chen DS, Colombo M, et al. Statements from the Taormina expert meeting on occult hepatitis B virus infection. J Hepatol. 2008 Oct;49(4):652-7.

33 Phillips S, Chokshi S, Riva A, Evans A, Williams R, Naoumov NV. CD8+ T cell control of hepatitis B virus replication: direct comparison between cytolytic and noncytolytic functions. J Immunol. 2010;184(1):287-95.

34 Ye B, Liu X, Li X, Kong H, Tian L, Chen Y. Tcell exhaustion in chronic hepatitis B infection: current knowledge and clinical significance. Cell Death Dis. 2016;6(3):e1694.

35 Sakaguchi S, Wing K, Onishi Y, Prieto-Martin P, Yamaguchi T. Regulatory T cells: how do they suppress immune responses? Int Immunol. 2009;21(10):1105-11.

36 Sawant DV, Vignali DA. Once a Treg, always a Treg? Immunol Rev. 2014;259(1):173-91.

37 Workman CJ, Szymczak-Workman AL, Collison LW, Pillai MR, Vignali DA. The development and function of regulatory $\mathrm{T}$ cells. Cell Mol Life Sci. 2009;66(16):2603.

38 Trehanpati N, Vyas AK. Immune regulation by $\mathrm{T}$ regulatory cells in hepatitis $\mathrm{B}$ virus-related inflammation and cancer. Scand J Immunol. 2017;85(3):175.

39 Perrillo RP. Current treatment of chronic hepatitis B: benefits and limitations. Seminars in liver disease. Thieme Medical Publishers, Inc; 2005. p. 20-8.

40 Lau DT, Bleibel W. Current status of antiviral therapy for hepatitis B. Therap Adv Gastroenterol. 2008;1(1):61-75.

41 Chisari FV, Isogawa M, Wieland SF. Pathogenesis of hepatitis B virus infection. Pathol Biol. 2010;58(4):258-66.

42 Ozaki K, Spolski R, Feng CG, Qi CF, Cheng J, Sher A, et al. A critical role for IL-21 in regulating immunoglobulin production. Science. 2002 Nov 22;298(5598):1630-4.

43 Crotty S. Follicular helper CD4 T cells (TFH). Annu Rev Immunol. 2011;29:621-63.

44 Breitfeld D, Ohl L, Kremmer E, Ellwart J, Sallusto F, Lipp M, et al. Follicular B helper T cells express CXC chemokine receptor 5, lo- calize to B cell follicles, and support immunoglobulin production. J Exp Med. 2000 Dec 4; 192(11):1545-52.

45 Schaerli P, Willimann K, Lang AB, Lipp M, Loetscher P, Moser B. CXC chemokine receptor 5 expression defines follicular homing $\mathrm{T}$ cells with B cell helper function. J Exp Med. 2000 Dec 4;192(11):1553-62.

46 Feng J, Lu L, Hua C, Qin L, Zhao P, Wang J, et al. High frequency of CD4+ CXCR5+ TFH cells in patients with immune-active chronic hepatitis B. PLoS One. 2011;6(7): e21698.

47 Schmitt N, Ueno H. Human T follicular helper cells: development and subsets. Adv Exp Med Biol. 2013;785:87-94.

48 Bentebibel SE, Khurana S, Schmitt N, Kurup P, Mueller C, Obermoser G, et al. ICOS $(+)$ PD-1(+)CXCR3(+) T follicular helper cells contribute to the generation of high-avidity antibodies following influenza vaccination. Sci Rep. 2016;6:26494.

49 Fahey LM, Wilson EB, Elsaesser H, Fistonich CD, McGavern DB, Brooks DG. Viral persistence redirects $\mathrm{CD} 4 \mathrm{~T}$ cell differentiation toward T follicular helper cells. J Exp Med. 2011 May 9;208(5):987-99.

50 Duan Z, Chen X, Liang Z, Zeng Y, Zhu F, Long L, et al. Genetic polymorphisms of CXCR5 and CXCL13 are associated with nonresponsiveness to the hepatitis $\mathrm{B}$ vaccine. Vaccine. 2014;32(41):5316-22.

51 Dono M, Zupo S, Leanza N, Melioli G, Fogli M, Melagrana A, et al. Heterogeneity of tonsillar subepithelial B lymphocytes, the splenic marginal zone equivalents. J Immunol. 2000; 164(11):5596-604.

52 Renand A, Milpied P, Rossignol J, Bruneau J, Lemonnier F, Dussiot M, et al. Neuropilin-1 expression characterizes $\mathrm{T}$ follicular helper (Tfh) cells activated during B cell differentiation in human secondary lymphoid organs. PloS One. 2013;8(12):e85589.

53 Vyas AK, Trehanpati N. Commentary: IL21 receptor antagonist inhibits differentiation of B cells toward plasmablasts upon alloantigen stimulation. Front Immunol. 2017;8:934

54 Claman HN, Chaperon EA, Triplett RF. Thymus-marrow cell combinations. Synergism in antibody production. Proc Soc Exp Biol Med. 1966 Aug-Sep;122(4):1167-71.

55 Vinuesa CG, Linterman MA, Yu D, MacLennan IC. Follicular helper T cells. Annu Rev Immunol. 2016 May 20;34:335-68.

56 Ma SW, Huang X, Li YY, Tang LB, Sun XF, Jiang XT, et al. High serum IL-21 levels after 12 weeks of antiviral therapy predict $\mathrm{HBeAg}$ seroconversion in chronic hepatitis B. J Hepatol. 2012 Apr;56(4):775-81.

57 Ye B, Liu X, Li X, Kong H, Tian L, Chen Y. Tcell exhaustion in chronic hepatitis B infection: current knowledge and clinical significance. Cell Death Dis. 2015;6(3):e1694.

58 Publicover J, Goodsell A, Nishimura S, Vilarinho S, Wang ZE, Avanesyan L, et al. IL-21 is pivotal in determining age-dependent effec- tiveness of immune responses in a mouse model of human hepatitis B. J Clin Invest. 2011 Mar;121(3):1154-62.

59 McGuire HM, Vogelzang A, Warren J, Loetsch C, Natividad KD, Chan TD, et al. IL-21 and IL-4 collaborate to shape T-dependent antibody responses. J Immunol. 2015; 195(11): 5123-35.

60 Weinstein JS, Herman EI, Lainez B, LiconaLimón P, Esplugues E, Flavell R, et al. TFH cells progressively differentiate to regulate the germinal center response. Nat Immunol. 2016;17(10): 1197.

61 Shulman Z, Gitlin AD, Weinstein JS, Lainez B, Esplugues E, Flavell RA, et al. Dynamic signaling by $\mathrm{T}$ follicular helper cells during germinal center B cell selection. Science. 2014 Aug 29;345(6200):1058-62.

62 Liu D, Xu H, Shih C, Wan Z, Ma X, Ma W, et al. T-B-cell entanglement and ICOSL-driven feed-forward regulation of germinal centre reaction. Nature. 2015 Jan 8;517(7533):2148.

63 Mesin L, Ersching J, Victora GD. Germinal center B cell dynamics. Immunity. 2016 Sep 20;45(3):471-82.

64 Kahan SM, Zajac AJ. Late arising T follicular helper cells cultivate the $\mathrm{B}$ cell crop during chronic infections. Sci Immunol. 2017 Dec 1; 2(18):eaap9339.

65 Shin C, Han JA, Koh H, Choi B, Cho Y, Jeong $\mathrm{H}$, et al. CD8 $\alpha(-)$ dendritic cells induce antigen-specific $\mathrm{T}$ follicular helper cells generating efficient humoral immune responses. Cell Rep. 2015;11(12):1929-40.

66 Saikia N, Talukdar R, Mazumder S, Khanna S Tandon R. Management of patients with HBeAg-negative chronic hepatitis B. Postgrad Med J. 2007;83(975):32-9.

67 Fattovich G, Zagni I, Scattolini C. Natural history of hepatitis B and prognostic factors of disease progression. J Hepatol. 2008 Feb; 48(2):335-52.

68 Liaw Y-F. HBeAg seroconversion as an important end point in the treatment of chronic hepatitis B. Hepatol Int. 2009;3(3):425-33.

69 Croagh CM, Lubel JS. Natural history of chronic hepatitis B: phases in a complex relationship. World J Gastroenterol. 2014;20(30): 10395.

70 Sharma SK, Saini N, Chwla Y. Hepatitis B virus: inactive carriers. Virol J. 2005;2(1): 82.

71 Fattovich G, Bortolotti F, Donato F. Natural history of chronic hepatitis B: special emphasis on disease progression and prognostic factors. J Hepatol. 2008;48(2):335-52.

72 Martinot-Peignoux M, Boyer N, Colombat M, Akremi R, Pham BN, Ollivier S, et al. Serum hepatitis B virus DNA levels and liver histology in inactive HBsAg carriers. J Hepatol. 2002;36(4):543-6.

73 van Bömmel F, Berg T. Stopping long-term treatment with nucleos $(\mathrm{t})$ ide analogues is a favourable option for selected patients with $\mathrm{HB}$ eAg-negative chronic hepatitis B. Liver Intern. 2018;38:90-6. 
74 Klein I, Crispe IN. Complete differentiation of CD8+ T cells activated locally within the transplanted liver. J Exp Med. 2006 Feb 20; 203(2):437-47.

75 Wuensch SA, Pierce RH, Crispe IN. Local intrahepatic CD8+ T cell activation by a nonself-antigen results in full functional differentiation. J Immunol. 2006 Aug 1;177(3):168997.

76 Greter M, Hofmann J, Becher B. Neo-lymphoid aggregates in the adult liver can initiate potent cell-mediated immunity. PLoS Biol. 2009 May 5;7(5):e1000109.

77 Publicover J, Gaggar A, Nishimura S, Van Horn CM, Goodsell A, Muench MO, et al. Age-dependent hepatic lymphoid organization directs successful immunity to hepatitis B. J Clin Invest. 2013 Sep;123(9):3728-39.

78 Lau GK, Wang FS. Uncover the immune biomarkers underlying hepatitis $\mathrm{B}$ e antigen (HBeAg) seroconversion: a need for more translational study. J Hepatol. 2012 Apr; 56(4):753-5.

79 Cooksley H, Chokshi S, Maayan Y, Wedemeyer H, Andreone P, Gilson R, et al. Hepatitis $\mathrm{B}$ virus e antigen loss during adefovir dipivoxil therapy is associated with enhanced virus-specific CD4+ T-cell reactivity. Antimicrob Agents Chemother. 2008 Jan;52(1):31220.

80 Xibing G, Xiaojuan Y, Juanhua W, Zhong H. Relationship between HBV genotypes B, C and follicular helper $\mathrm{T}$ cells in patients with chronic hepatitis B and its significance. Hepat Mon. 2013;13(1):e6221.

81 Shrivastava S, TrehanPati N, Kottilil S, Sarin SK. Decline in immature transitional B cells after hepatitis B vaccination in hepatitis B positive newborns. Pediatr Infect Dis J. 2013 Jul;32(7):792-4.
82 Vyas AK, Negi P, Patra S, Maras JS, Ramakrishna G, Sarin SK, et al. Maternal immunity influences vertical transmission of hepatitis B to newborns. Hepatol Commun. 2019;3(6): 795-811.

83 Krause A, Haberkorn U, Mier W. Strategies for the treatment of HBV/HDV. Eur J Pharmacol. 2018 Aug 15;833:379-91.

84 Woo ASJ, Kwok R, Ahmed T. Alpha-interferon treatment in hepatitis B. Ann Transl Med. 2017 Apr;5(7):159.

85 Spyrou E, Smith CI, Ghany MG. Hepatitis B: current status of therapy and future therapies. Gastroenterol Clin North Am. 2020 Jun; 49(2):215-38

86 Lahlali T, Berke JM, Vergauwen K, Foca A, Vandyck K, Pauwels F, et al. Novel potent capsid assembly modulators regulate multiple steps of the hepatitis B virus life cycle. Antimicrob Agents Chemother. 2018 Oct;62(10): e00835-18.

87 Pu D, Yin L, Zhou Y, Li W, Huang L, Cai L, et al. Safety and efficacy of immune checkpoint inhibitors in patients with $\mathrm{HBV} / \mathrm{HCV}$ infection and advanced-stage cancer: a systematic review. Medicine. 2020 Jan;99(5):e19013.

88 Fanning GC, Zoulim F, Hou J, Bertoletti A. Therapeutic strategies for hepatitis B virus infection: towards a cure. Nat Rev Drug Discov. 2019 Nov; 18(11):827-44.

89 Sekiba K, Otsuka M, Ohno M, Yamagami M, Kishikawa T, Suzuki T, et al. Inhibition of HBV transcription from cccDNA With nitazoxanide by targeting the HBx-DDB1 interaction. Cell Mol Gastroenterol Hepatol. 2019; 7(2):297-312

90 Maepa MB, Roelofse I, Ely A, Arbuthnot P. Progress and prospects of anti-HBV gene therapy development. Int J Mol Sci. $2015 \mathrm{Jul}$ 31;16(8):17589-610.

91 Ma Z, Zhang E, Gao S, Xiong Y, Lu M. Toward a functional cure for hepatitis $B$ : the rationale and challenges for therapeutic targeting of the B cell immune response. Front Immunol. 2019;10:2308.
92 Lucifora J, Bonnin M, Aillot L, Fusil F, Maadadi S, Dimier L, et al. Direct antiviral properties of TLR ligands against HBV replication in immune-competent hepatocytes. Sci Rep. 2018 Mar 29;8(1):5390.

93 Storni T, Ruedl C, Schwarz K, Schwendener RA, Renner WA, Bachmann MF. Nonmethylated CG motifs packaged into virus-like particles induce protective cytotoxic $\mathrm{T}$ cell responses in the absence of systemic side effects. J Immunol. 2004 Feb 1;172(3):1777-85.

94 Golsaz-Shirazi F, Shokri F. Hepatitis B immunopathogenesis and immunotherapy. Immunotherapy. 2016;8(4):461-77.

95 Kimura K, Kakimi K, Wieland S, Guidotti LG, Chisari FV. Interleukin-18 inhibits hepatitis B virus replication in the livers of transgenic mice. J Virol. 2002 Nov;76(21):10702-7.

96 Xia Y, Protzer U. Control of hepatitis B virus by cytokines. Viruses. 2017 Jan 20;9(1):18.

97 Schon HT, Weiskirchen R. Immunomodulatory effects of transforming growth factor- $\beta$ in the liver. Hepatobiliary Surg Nutr. 2014 Dec;3(6):386-406.

98 Dou Y, van Montfoort N, van den Bosch A, de Man RA, Zom GG, Krebber WJ, et al. HBVderived synthetic long peptide can boost CD4+ and CD8+ T-cell responses in chronic HBV patients ex vivo. J Infect Dis. $2018 \mathrm{Feb}$ 14;217(5):827-39.

99 Boni C, Barili V, Acerbi G, Rossi M, Vecchi A, Laccabue D, et al. HBV immune-therapy: from molecular mechanisms to clinical applications. Int J Mol Sci. 2019;20(11):2754.

100 Kruse RL, Shum T, Tashiro H, Barzi M, Yi Z, Whitten-Bauer C, et al. HBsAg-redirected T cells exhibit antiviral activity in $\mathrm{HBV}$-infected human liver chimeric mice. Cytotherapy. 2018;20(5):697-705. 